\title{
THE ROLE OF PURCHASE INTENTION ON MEDIATING THE RELATIONSHIP OF E-WOM AND E-WOM CREDIBILITY TO PURCHASE DECISION
}

\author{
Arta I Gede Subana*, Yasa Ni Nyoman Kerti \\ Faculty Economic and Business, University of Udayana, Bali, Indonesia \\ *E-mail: subanaarta@gmail.com
}

\begin{abstract}
The aim of this study is explaining the impact of E-WOM (e-WOM) and e-WOM credibility towards purchase decision, with purchase intention as a mediator variable. There is a total response of 115 people collected by using purposive sampling technique. Furthermore, the selected respondents have the following criteria: (a) actively using social media, such as Facebook and Instagram; (b) read the testimonials, photos, and location of a restaurant on social media; (c) have experienced the previously described restaurant; and (d) have graduated from high school. The hypothesis in this study was prepared with Generalized Structured Component Analysis (GeSCA) technique.From the research that has been carried out, it is possible to conclude that: (a) e-WOM has positive and significant influence towards e-WOM credibility; (b) e-WOM encourages the purchase intention; (c) e-WOM has no direct positive and significant effect towards restaurant customers' purchase decision in Bali, but it affects indirectly through their purchase intention; (d) e-WOM credibility has positive and significant influence towards purchase intention; (e) e-WOM credibility has positive and significant influence towards purchase decision, directly and indirectly; and (f) purchase intention has a positive relationship with purchase decision.
\end{abstract}

\section{KEY WORDS}

E-WOM, e-WOM credibility, purchase intention, purchase decision.

Internet users in Indonesia make up for information updates as the main reason for their use, which are 31.3 million users. The same data also found that $97.4 \%$ or 129.2 million internet users were social media users. There are lots of social media in the world, starting from Facebook, Twitter, Instagram, and many more that already exist and will still develop. The development of social media certainly can be used as one of the promotional media for a business, such as a restaurant business for example. For social media content that is most frequently visited by Indonesian internet users, it is still led by Facebook with 71.6 million users or $54 \%$, then Instagram with 19.9 million users or $15 \%$.

Seeing the large number of social media users, it is possible for someone to get information, both positive information and negative information from social media. Through this social media, Information can spread rapidly and widely repeatedly from one user to another social media user, which might unwittingly trigger the emergence of E-WOM (EWOM). Through this social media, customers can express what they feel and what they want. Potential customers can read this and allow for a purchase intention to arise from what the customer previously felt.

Companies will increasingly benefit from this situation. Companies can take advantage of interactive communication between customers. They can build networks to create E-WOM that is good about their product offerings. Today many restaurants in Bali are starting to grow and benefit from this situation. Customers begin to share their experiences with the restaurant often in the form of writing and photos that they upload on their personal social media such as using social media Facebook and Instagram. Customers share their impressions of the convenience of the place, the variety of menus and taste of the restaurant, and often also share the location of restaurants. So that new potential customers can indirectly experience the restaurant and allow it to arise to try to experience directly at the restaurant. 
Purchase intention is a process of deciding whether to use or not a product. According to Murwatiningsih and Apriliani (2013) purchase intention is generally used to understand the purpose of consumers in making a purchase decision. Purchase intention arises after an alternative evaluation process and in the evaluation process, someone will make a series of choices regarding the product to be purchased on the basis of brand and intention. The customer evaluation process starts when they see someone else's writing or photo about a restaurant. Prospective customers will sort out a lot of the information they get through other people's social media and adjust which restaurant is according to their intentions based on the information they get.

Schiffman and Kanuk (2009) state that purchase decisions are a process of determining choices from two or more alternative choices of purchase decisions. From the statement, it can be interpreted that someone or prospective customer must get a lot of information choices through social media which will cause purchase intention towards a restaurant product which will then continue to be the restaurant product purchase decision.

Communication Word of mouth (WOM) is informal communication between customers about a product or service that is considered the most important information in a purchase because it has a strong impact on customer behavior Jeong et al. (2011). Word of mouth plays a big role in its influence on consumer purchase decisions in the formation of consumer behavior patterns (Jalilvand, 2012). With the advancement of internet technology, web-based WOM (E-WOM) has expanded widely, where unlike traditional WOM, E-WOM can spread faster and wider and have a stronger impact.

In E-WOM, source credibility can be considered an important factor in decision makers (Park and Lee, 2009). In one study, Lopez and Sicilia (2014) emphasized that expertise and trust are most often used to test the credibility of sources. when customers read product information, reviews, and recommendations, they must rely on their own expertise and involvement to determine E-WOM credibility. E-WOM credibility is the extent to which customers feel that product information, reviews, or recommendations are factual, correct, or reliable (Cheung et al., 2009).

Seeing the reality that exists in the community in Bali, it will be tested whether E-WOM influences the purchase intention of someone who has seen E-WOM on social media, and later $\mathrm{n}$ whether this purchase intention will change into a purchase decision. E-WOM is also linked to E-WOM credibility, which will then be tested for its influence on purchase intentions and purchased ecisions. This study will also examine whether there is a mediating role of purchase intention between E-WOM and purchase decisions, and between E-WOM credibility and purchase decisions and the mediating role of E-WOM credibility between EWOM and purchase decisions. This phenomenon is raised because it needs to be measured whether E-WOM can be used as a good marketing medium for restaurants in Bali. As is known, marketing is something that often burdens a company's budget because of the high cost. But with E-WOM in place, there will be an increase in budget effectiveness in the company. In addition to the cost problem, in previous studies there were also positive and negative results between E-WOM's relationship with the intention to buy. One negative result is in the study of Shahrinaz et al., (2016) who conducted research in Sarawak, obtaining a negative relationship between E-WOM and purchase intention for consumers of smart phones. In this study also carried out testing with integrated variables which are the renewability of this study.

\section{LITERATURE REVIEW}

The Effect of E-WOM on E-WOM Credibility. Hennig-Thurau et al. (2004) state that EWOM is unsolicited, that is, it can be sent to those who are not in need of any information about a product or service and do not necessarily want to receive such information, and EWOM allows communication without face to face between the two parties. In E-WOM, source credibility can be considered an important factor in decision makers (Park and Lee 2009). In one study, Lopez and Sicilia (2014) emphasized that expertise and trust are most often used to test the credibility of sources. Doh and Hwang (2009) who investigated how consumers 
evaluate E-WOM messages, some negative messages can help in promoting a positive attitude towards the website and the credibility of E-WOM messages.

$\mathrm{H} 1$ : E-WOM has a positive and significant effect on E-WOM credibility.

The Effect of E-WOM on purchase intentions. Elseidi et al. (2016) who conducted research in Egypt, found that there was a positive influence from E-WOM on purchase intentions on smartphone consumers. Hennig-Thurau et al. (2004) state that E-WOM is unsolicited, that is, it can be sent to those who are not in need of any information about a product or service and do not necessarily want to receive such information, and E-WOM allows communication without face to face between the two parties. The study conducted by Elseidi et al. (2016); Jang (2011) and Hennig-Thurau et al. (2004) stated that E-WOM had a positive and significant effect on purchase intention.

H2: E-WOM has a positive and significant effect on purchase intention.

The Effect of E-WOM on purchase decisions. Senecal and Nantel (2004) examined how E-WOM influences product choices using experimental studies regarding the use of online recommendation sources by consumers. Some related studies also show that E-WOM is an important means by which consumers can obtain information about the quality of products or services (Chevalier and Mayzlin, 2006). In addition, this kind of message can effectively reduce the risks and uncertainties that are recognized by consumers when buying products or services, so that their purchase intentions and decision making can be more influenced (Chatterjee, 2001).

H3: E-WOM has a positive and significant effect on purchase decisions.

The Effect of E-WOM credibility on purchase intentions. Sharif et al. (2016) who conducted a study of the effect of E-WOM credibility on purchase decisions found positive and significant results in the study. In one study, Lopez and Sicilia (2014) emphasized that expertise and trust are most often used to test the credibility of sources. Doh and Hwang (2009) who investigated how consumers evaluate E-WOM messages, some negative messages can help in promoting a positive attitude towards the website and the credibility of E-WOM messages. This might be quite reasonable, because some consumers might suspect the credibility of a website or a collection of several E-WOM messages if they barely find a negative message. Engagement is associated with motivation to process information.

H4: E-WOM credibility has a positive and significant effect on purchase intention.

The Effect of E-WOM credibility on purchase decisions. E-WOM acceptance is based on social norms or opinions in the virtual community. Readers build E-WOM credibility at the beginning of the evaluation process (Wathen and Burkell, 2002). If the reader determines that reviews or opinions can be trusted, they are more confident to receive E-WOM contained in reviews or opinions (Sussman and Siegel, 2003). They are also more confident to use E-WOM to make purchase decisions.

H5: E-WOM credibility has a positive and significant effect on purchase decisions.

The Effect of purchase intentions on purchase decisions. Khandelwal et al. (2013) who conducted research in India on online travel consumers found that there was a significant effect of purchase intention on purchase decisions. Likewise, the study conducted by Mramba (2015); Prasad et al. (2014) and Simpson \& Mortimore (2015) state that purchase intention has a positive and significant effect on purchase decisions.

H6: Purchase intention has a positive and significant effect on purchase decisions.

The role of purchase intention as a mediating E-WOM and purchase decisions. Jang (2011) in research focusing on restaurant customers who spread E-WOM positively, there were three dimensions of E-WOM, namely concern for others, expressing positive feelings, and helping the company. Whereas Hennig-Thurau et al. (2004) found eight dimensions in EWOM, namely platform assistance, Venting negative feelings, concern for the others, extraversion / positive self-enhancement, social benefits, economic incentives, helping the company, and advice seeking. In this research, it will only focus on three dimensions, namely economic incentives, expressing positive feeling, and concern for the others.

Consumer purchase intention can also be caused by external influences, awareness of needs, product introduction, and alternative evaluations of Schiffman \& Kanuk (2007). Super and Crities (1998) state that intention is something personal and related to attitude. Someone 
who is interested in something will have the urge to take a series of actions to get it. Purchase decisions are actions of consumers to buy a product. Purchase decisions are a process of determining choices from two or more alternative choices (Schiffman and Kanuk, 2009). The study conducted by Jang (2011) and Hennig-Thurau et al. (2004) stated that economic incentives, positive expres- sion of feeling, concern for the others had a positive and significant effect on purchase intention. The study conducted by Kassim and Abdullah (2010) states that there is a positive and significant influence on purchase decisions. Likewise, the study conducted by Mramba (2015); Prasad et al. (2014) and Simpson and Mortimore (2015) state that purchase intention has a positive and significant effect on purchase decisions.

$\mathrm{H7}$ : Purchase intention acts as a mediating variable between E-WOM and purchase decisions.

The role of purchase intention as a mediating variable between E-WOM credibility and purchase decisions. Consumer purchase intention can be caused by external influences, awareness of needs, product introduction, and alternative evaluations of Schiffman and Kanuk (2007). According to Murwatiningsih and Apriliani (2013) purchase intention is generally used to understand the purpose of consumers in making a purchase decision. Purchase decisions are actions of consumers to buy a product. Purchase decisions are a process of determining choices from two or more alternative choices (Schiffman and Kanuk, 2009). In E-WOM, source credibility can be considered an important factor in decision makers (Park and Lee 2009). In one study, Lopez and Sicilia (2014) emphasized that expertise and trust are most often used to test the credibility of sources. Based on the previous description, the following hypotheses can be arranged:

H8: Purchase intention acts as a mediating variable between E-WOM credibility and purchase decisions

The role of E-WOM credibility as a mediating variable between E-WOM and purchase decisions. Senecal and Nantel (2004) examined how E-WOM influences product choices using experimental studies regarding the use of online recommendation sources by consumers. In E-WOM, source credibility can be considered an important factor in decision makers (Park and Lee 2009). In one study, Lopez and Sicilia (2014) emphasized that expertise and trust are most often used to test the credibility of sources. Some related studies also show that E-WOM is an important means by which consumers can obtain information about the quality of products or services (Chevalier \& Mayzlin, 2006).

H8: E-WOM credibility acts as a mediating variable between E-WOM and purchase decisions.

\section{METHODS OF RESEARCH}

Population and Samples. The population in this study is all restaurant customers in Bali who are actively using social media that is not known in exact numbers. Samples in this study were determined by non probability sampling methods. In this study there were 21 indicators, so that the good sample size range was 5-10 times the number of samples which was $105 \leq n \leq 210$. Based on that range, by considering the available resources, the sample size was determined in 115 people.

Data collection technique. In this study, data collection used a questionnaire, namely data collection techniques carried out with a questionnaire or a list of written statements distributed to all respondents.

Data analysis technique. This study will use the GeSCA data analysis method. The use of GeSCA as an analytical tool is as a renewal in this study, besides that the GeSCA analysis tool also facilitates reading the results.

\section{RESULTS OF STUDY}

Based on the estimated model value that has been formed from the results of the analysis, it can be seen that the E-WOM and E-WOM Credibility variables play a role in 
influencing purchase intention so that restaurants that have high E-WOM and E-WOM credibility can effect consumers in making purchase decisions.

The estimate value and standard error (SE) of E-WOM variables are 0.576 and 0.100 with a critical point value of 5.79 , which is significant at the 95 percent confidence level. Thus $\mathrm{HO}$ is rejected. This means that E-WOM has a positive and significant effect on E-WOM credibility. This is consistent with the research of Lopez and Sicilia (2014) and Sharif et al. (2016) who found a positive correlation between E-WOM and E-WOM Credibility.

The estimate value and standard error (SE) of E-WOM variables are 0.447 and 0.085 with a critical point value of 5.23 , which is significant at the 95 percent confidence level. Thus $\mathrm{HO}$ is rejected. Means E-WOM has a positive and significant effect on Purchase Intentions. This is consistent with research from Hennig-Thurau et al. (2004) and Elseidi \& Dina (2016).

The estimate value and standard error (SE) of E-WOM variables are 0.168 and 0.087 with the critical point value of 1.94, not significant at the 95 percent confidence level. Thus $\mathrm{HO}$ fails to be rejected. Means that E-WOM has no significant effect on Purchase Decisions. This is contrary to the results of research from Matute Et al. (2016) and research from Hafsa et al. (2017) in his research entitled impact of social networking sites on consumer purchase intention: an analysis of restaurants in karachi, where they found that E-WOM had a significant effect on purchase decisions.

Estimated values and standard error (SE) of E-WOM Credibility variables are 0.484 and 0.092 with a critical point value of 5.29 , significant at the 95 percent confidence level. Thus $\mathrm{HO}$ is rejected. This means that E-WOM Credibility has a positive and significant effect on purchase intention. The better E-WOM Credibility, the greater the purchase intention of the customer is to choose the restaurant. This is consistent with research from Sharif et al. (2016) as well as research by Doh and Hwang (2009) who investigated how consumers test and evaluate source credibility.

The estimate value and standard error (SE) of E-WOM Credibility variables are 0.393 and 0.106 with a critical point value of 3.72 , which is significant at the 95 percent confidence level. Thus $\mathrm{HO}$ is rejected. It means that E-WOM Credibility has a positive and significant effect on the Purchase Decision. The better the E-WOM Credibility, the greater the customer's decision to choose the restaurant. This is consistent with research from Sharif et al. (2016) and research from Park and Lee (2009) who consider source credibility as an important factor in decision making.

The estimate value and standard error (SE) of purchase intention variables are 0.332 and 0.111 with a critical point value of 3.00 , significant at the 95 percent confidence level. Thus $\mathrm{HO}$ is rejected. It means that purchase intention has a positive and significant effect on the Purchase Decision. The higher the purchase intention, the greater the customer's decision to choose the restaurant. This is consistent with research from Simpson and Mortimore (2015) and Matute et al. (2016) which states that purchase intention has a positive and significant effect on purchase decisions.

Based on the results of data analysis it was found that intention to mediate E-WOM's influence on purchasing decisions. This is indicated by the value of $Z$ is 5.696 . A value of 5.696 is greater than the critical value of 1.96 . This means buying intention acts as a variable that mediates the relationship between E-WOM and purchasing decisions. This result is also in accordance with the research conducted by Sharif et al. (2016) and Hennig-Thurau et al. (2004) entitled Electronic Word-of-mouth via consumer opinion platforms.

Based on the results of data analysis, it was found that intention to mediate the effect of E-WOM credibility on purchasing decisions. This is indicated by the value of $Z$ is 4.175 . The value of 4.175 is greater than the critical value of 1.96 . This means that purchase intention acts as a variable that mediates the relationship between E-WOM credibility and purchasing decisions. This result is also in accordance with the research conducted by Lopez and Sicilia (2014) and the research conducted by Park and Lee (2009).

Based on the results of data analysis, it was found that E-WOM Credibility can mediate the effect of E-WOM on purchasing decisions. This is indicated by the value of $Z$ is 5.041 . The value of 5.041 is greater than the critical value of 1.96 . This means that E-WOM credibility acts as a variable that mediates the relationship between E-WOM and purchasing 
decisions. This result is also in accordance with the research conducted by Park and Lee (2009) and Lopez and Sicilia (2014) which together emphasize the credibility of the source.

\section{CONCLUSION}

E-WOM has a positive and significant effect on E-WOM credibility for restaurant customers in Bali. E-WOM has a positive and significant influence on buying intention for restaurant customers in Bali. E-WOM has no significant effect on purchasing decisions on restaurant customers in Bali. E-WOM Credibility has a positive and significant effect on buying intention for restaurant customers in Bali. E-WOM Credibility has a positive and significant effect on purchasing decisions on restaurant customers in Bali. Buying intention has a positive and significant effect on purchasing decisions on restaurant customers in Bali. Buying intention acts as a variable that mediates fully or perfectly the relationship between EWOM and purchasing decisions at restaurant customers in Bali. Buy intention acts as a variable that mediates the relationship between E-WOM credibility and purchasing decisions at restaurant customers in Bali. E-WOM credibility acts as a variable that mediates relationships between E-WOM and purchasing decisions for restaurant customers in Bali.

\section{SUGGESTIONS}

The suggestion that can be conveyed in this research is that restaurant is very important to pay attention to E-WOM credibility because it plays a very important role in determining purchasing decisions. From the results of the study, buyers were very concerned about the taste of the food served, as well as the comfort of the restaurant. If the restaurant succeeds in providing a good experience of this, it will also produce good E-WOM credibility so that it can increase customer confidence in deciding to shop at the restaurant so that it will have an impact on sales volume. It should also be noted by restaurant owners that interaction with social media accounts gets little results in this study, so that if it is successfully upgraded, it might provide better results for restaurants.

Future research can do research by dividing the respondent's area according to the regencies / cities in Bali. Subsequent research can also narrow down the types of social media used as indicators of research.

\section{REFERENCES}

1. Chatterjee, P. 2001. Online reviews: do consumers use them? Advances in Consumer Research, Vol. 28 No. 1, pp. 129-33.

2. Cheung, M., Luo, C., Sia, C. and Chen, H. 2009. Credibility of electronic word-of-mouth: Informational and normative determinants of on-line consumer recommendations. International Journal of Electronic Commerce, Vol. 13, No. 4, pp. 9-38.

3. Chevalier, J.A. and Mayzlin, D. 2006. The effect of word of mouth on sales: online book reviews. Journal of Marketing Research, Vol. 43 No. 3, pp. 345-54.

4. Doh S.-J. and Hwang, J.-S. 2009. How Consumers Evaluate E-WOM (Electronic Wordof-Mouth) Messages. CyberPsychology \& Behavior. Vol. 12, No. 2, pp. 193-197

5. Elseidi, R. I. and Dina, E. 2016. E-WOM effects on consumers' brand attitudes, brand image and purchase intention: an empirical study in Egypt. The Business \& Management Review.London. Vol. 7, Iss. 5, pp. 268-276

6. Hennig-Thurau, T., Gwinner, K.P., Walsh, G. and Gremler, D.D. 2004. Electronic word-ofmouth via Consumer Opinion Platforms: What Motivates Consumers to Articulate Themselves on the Internet. Journal of Interactive Marketing. Vol. 18, No. 1, pp. 38-52.

7. Kassim, N. and Abdullah, N. A. 2010. The Effect of Perceived Service Quality Dimensions on Customer Satisfaction, Trust, and Loyalty in E-Commerce Settings, Asia Pacific Journal of Marketing and Logistics, Vol. 22 No. 3, pp. 351-371.

8. Khandelwal, U., Bajpai, N. and Sharma, J. P. 2013. Purchase Intention of Indian Consumers on Online Travel Buying Decision: A Comparative Study on Metro and Non- 
Metro City. International Journal of Hospitality and Tourism Systems. Vol. 6, Iss. 1, pp 13-22.

9. Lopez, M. and Sicilia, M. 2014. Determinations of E-WOM Influence: The Role of Consumers' Internet Experience. Journal of Theoretical and Applied Electronic Commerce Research, Vol. 9, No. 1, pp. 28-43. Mangold, Glynn. 1999. Word of Mouth Communication in the Service Marketplace. The Journal of Services Marketing. Santa Barbara.

10. Mramba, N. 2015. Does the Brand Name Matter to Purchase Decision? The Case of Mobile Phone. Europeanjournal of Business and Management, Vol.7, No.4, pp.19052222.

11. Murwatiningsih dan Apriliani, E. P. 2013. Pengaruh Resiko dan Harga Terhadap Keputusan Pembelian Melalui Kepercayaan Konsumen. Jurnal Dinamika Manegemen.

12. Park, C. and Lee, T. M. 2009. Information Direction, Website Reputation and E-WOM Effect: A Moderating Role of Product Type, Journal of Business Research, Vol. 62, pp. 61-67

13. Prasad, Shantanu., Totala, N.K., \& Gupta, I.C. 2014. Social Media and Customer Purchase Decision. American Internasional Journal of Research in Humanities, Arts and Social Sciences, 2328-3090. http://www.iasir.net.

14. Schiffman, L. And Kanuk, L. L. 2009. Consumer Behavior, Edisi Ketujuh. Patience Hall International, inc. New Jersey.

15. Senecal, S. and Nantel, J. 2004. The influence of online product recommendations on consumers' online choices. Journal of Retailing. Vol. 80 No. 2, pp. 159-69.

16. Shahrinaz, I. 2016. Relationship and impact of e-WOM and brand image towards purchase intention of smartphone? Journal of Scientific Research and Development 3 (5): 117-124.

17. Sharif, M. A., Ahmad, W. and Ahmad, A. 2016. E-WOM: investigating the influence of electronic message source credibility, message appeal and brand equity on consumer purchase intention. City University Research Journal, Vol. 6, Iss. 1, 151-165.

18. Simpson, J. and Mortimore, H. 2015. The Influence of direct mail marketing on buyer purchasing decision: A qualititive analysis of perception by age group.JRSBM: 1/1 pp 119-142.

19. Sussman, S. W. and Siegel, W. S. 2003. Informational influence in organizations: An integrated approach to knowledge adoption inform. Systems Research, Vol. 14, No. 1, pp. 47-65

20. Wathen, C. N. and Burkell, J. 2002. Believe it or not: Factors influencing credibility on the Web. Journal of the American Society for Information Science and Technology, Vol. 53, No. 2, pp. 134-144. 